\title{
Initiating a different story about immigrant Somali parents' support of their primary school children's education
}

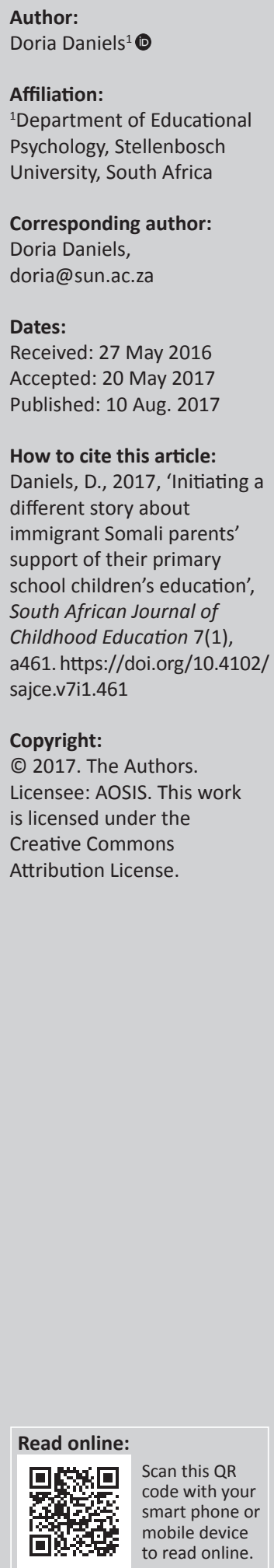

\begin{abstract}
The ability of parents to nurture and support their children during their primary school years is considered to be fundamental for the child's development and learning. Teachers and educational psychologists assign great prominence to parental involvement as a tool to advance educational success for children, especially for those who are faced with disadvantages. In the past two decades, we have seen South African schools radically shifting from being racially and ethnically homogenous to becoming culturally, ethnically and linguistically heterogeneous. It is especially the schools in the lower socioeconomic areas that find themselves under tremendous pressure to serve their growing immigrant school population. Not enough is known about the cultural capital that lies embedded in these learners' home contexts and the roles that their parents play in their education. In this manuscript, I investigate the potential intersectionality of school and home and critique the affiliation between teachers and immigrant parents as an important dimension of learning success in the primary school. I situate the discussion in a community school with a strong Somali immigrant population.
\end{abstract}

\section{Introduction}

In most societies, education is regarded as the key to social progress, with active parental involvement being considered a vital component of the child's educational success in primary school. The ability of parents to nurture and support their children during the primary school years is considered to be fundamental for the child's development and learning (Christian, Morrison \& Bryant 1998; Epstein 2001; Henderson \& Mapp 2002; Jeynes 2007). Teachers and educational psychologists assign great prominence to parental involvement as a tool to advance educational success for children, especially for those who are faced with disadvantages (Jeynes 2005; McBride \& Lin 1996). Social researchers, too, have pointed out the saliency of parental involvement in urban societies, with their non-traditional family structures and their unique sociological pressures on children (Bauch \& Goldring 1995; Bernstein 2004; Hampton, Mumford \& Bond 1998; Singh, Mbokodi \& Msila 2004).

All the research on educational involvement highlights the intersection of school and home and the importance of teacher-parent affiliations in educational success. According to Bernstein (2004), achieving such success is dependent on two complementary sites of pedagogic acquisition: the school and the home. He argues that educational acquisition is strengthened and augmented by the home context through assigning official pedagogical time at home to do homework and establishing contexts in which control is exercised to keep the child on task with the homework.

While the intersection of school and home and communication between teachers and parents are identified as important dimensions of learning success, they are seldom afforded the critical inspection they deserve. Educational quality and school success tend to be explained only with reference to educational materials and teachers. Research shows that when educators talk about parental involvement, they draw on a false sense of knowing the home contexts of the students and their parents (Lareau 1989; Li 2010; Waterman 2008). Thus, when family-school relationships are critiqued, only discourses that flow through the formal and informal curricula are considered, while the discourses present in families and communities are largely overlooked. The potential of the home as an educational site and the parents as strategic partners of education are largely unacknowledged in such discourse.

A home context that educators presume to be challenging, but which educational researchers seldom consider important enough to understand, is that of the working-class immigrant. I acknowledge that the immigrant experience is complex and diverse, informed as it is by socioeconomic status, race and 
culture. For this reason, I have limited my focus here to the context of the Somali immigrant family. I seek to advance an understanding of the effect of immigration on the lives of a community of working-class Somali families in South Africa. My assumption is that parents' own educational experiences will define their role in their children's education, as informed by their intentions, abilities, interests and ways of seeing their children's educational worlds. This may be very different from that of South African-born parents, whose cultures and societies may have socialised them to engage with education in different ways. My concern is that, because of a lack of adequate understanding by the schools of the cultural, linguistic and religious challenges that immigrant families face when they navigate their host country's ways, educators could see deficits rather than strengths in such learners and their parents.

A body of research already exists that attempts to speak back to assumptions and attitudes about immigrant parents, showing how they do care and have other ways of showing that caring, ways which are not often recognised by schools (Delgado-Gaitan 1992; López 2001; Orellana, Monkman \& MacGillivray 2002). However, none of this research has been conducted in South African contexts. South African research on the immigrant home as a pedagogical acquisition site could advance an understanding of the life worlds and the challenges embedded within them for learners who come from such homes. The deconstruction of parental investment in such contexts could lead to a new understanding of parent support and to an informed understanding of the various permutations of such support.

\section{The research}

The context for this study was a Western Cape community. The aim was to research the experiences of immigrant Somali parents of giving educational support to their primary school children, their investment in their children's education and bringing into the discussion their unique challenges with navigating formal education. For the discussion, I drew on data of my narrative inquiry as well as a master's study (Peters 2014) that I supervised, in the same community. My thinking about these parents' worlds was informed by social constructionism. I presumed that the stories the immigrant parents would tell of educational support would be coconstructions derived from their own educational histories, their engagements with the host country's educational system, and their conversations with the researcher. My contention was that all these influences intersect and shape the parents' thinking and actions relating to the education of their children. I found support in the writing by Liamputtong and Ezzy (2005:132) which locates narratives 'at the intersection of history, biography and society'.

The local school served as intermediary to the community. The school's secretary facilitated an introduction between myself and one of the parents, after which, through a snowballing process of sampling, I was introduced to other community members, of whom three more women became participants. My prior cross-cultural research highlighted how communication (Daniels 2003) between researcher and research population can be hampered by the lack of a shared language. Chase (2005) recognises five interrelated analytical lenses when analysing narrative data: narrative as vehicle for human action, narrator voice, social circumstances as constraints to narrations, social situatedness of the narrative and the researcher as narrator. I was especially concerned that the richness and authenticity of the narrators' voices would be compromised if they were to narrate their stories through a translator. This influenced my decision to limit participation to those who could converse in English. The participants were all women. There was one main reason for this: most of the men were unavailable to take part in the research as they all worked outside of the community. I used interviewing as the primary method for data collection (Creswell 2003; Mertens 2014). This was facilitated through semi-structured personal interviews with mothers and two focus group interviews with educators who taught Somali children in their classes (Patton 2002; Terre Blanche, Durrheim \& Painter 2006). In the first part of the article, I give an overview of the educational landscape and review the literature on parental support. In the second part, I contextualise my discussion both through my own preliminary findings and as informed by Peters's (2014) study.

\section{Educational transformation, access and inclusion}

The South African government subscribes to an inclusive education ethos for its schools. This is based on a value system that invites and celebrates diversity of gender, nationality, race, language, socioeconomic background, cultural origin and level of educational achievement (Swart \& Pettipher 2011). The Universal Declaration on Human Rights (1948) and the UNESCO Convention against Discrimination in Education (1960) affirm education as a human right. The South African government's commitment to inclusion is written in its constitution and serves as a guide to redress past inequalities and create equal opportunities for all children by developing an education system that respects each child's right to an education (Republic of South Africa 1996b). This transformational process has been characterised by equitable initiatives such as the better resourcing of schools and the broadening of educational opportunities, especially for South Africa's Black populations who, under apartheid, were denied access to quality education and had limited opportunities to advance academically.

Though great successes have been seen in education, many challenges remain which threaten educational success, especially in the lower socioeconomic community schools. Immigration is one such challenge. The past two decades have seen a radical shift from racially and ethnically homogenous South African school communities to culturally, ethnically and linguistically heterogeneous school communities. South Africa's inclusion policy (DoE 2004) provides access to all children, irrespective of their nationality, ethnicity, culture or linguistic background. A South Australian study that 
investigated the ways in which social inclusion was understood in government primary schools (Gill 2008) identified the pivotal role that schools play in the development and growth of a community. The term 'social inclusion' is used quite liberally in South Africa's educational policies, mostly to focus on the principles needed for the establishment of social opportunities for the marginalised, which include immigrant communities.

However, the government's almost uncritical subscription to the humanitarian premise of also giving children of foreign nationality access to South African schools is adding to the challenges that are faced by most under-resourced state schools. My raising of this issue is not to be read as agitating for the denial or restriction of access to the benefits of education by immigrant populations; rather I am alluding to the complexities and challenges that come with uncritical access. Educational policy documents are theoretical interpretations of the ideal; they do not delve into the ethnic, cultural or linguistic complexities of state schools, nor do they engage with the way barriers to learning in the multiethnic classroom could hinder schools from reaching the goals of a quality education. Seldom do policies stipulate a requirement that teachers be knowledgeable about the diverse pedagogical spaces their learners inhabit. I believe that teachers who are empowered with knowledge about the diverse South African communities will see the potential of parents as collaborators who can help to address the challenges their children face in class. Lack of knowledge about the investments such parents make in their children's education, on the other hand, may create a perception that immigrants are taking educational opportunities away from South Africans, one which may go unchallenged.

\section{Parent involvement or parent support?}

My understanding of parental involvement focuses on their participation in the educational processes and experiences of their children. Educational reforms in South Africa over the last two decades have encouraged parents to take on increased responsibilities in the governing of schools (Lemmer 2007). The South African Schools Act (SASA) of 1996 gave parents legal power to take more central roles in their children's schools. Through the SASA, opportunities now exist for parents to become partners with teachers in the governance of schools, as well as collaborators in bringing about quality education (Singh et al. 2004). Unfortunately, this has not always happened, as parents continue to be peripheral actors on the educational stage. In challenging school contexts, teachers continue to blame parents for limited investment in their children's education. Lareau's (2002) research has shown that teachers make a link between the problems they have with their learners in school and the parents' lack of involvement in their education.

The international literature on models of parent involvement is largely informed by the work of Joyce Epstein $(1985,1995,2001)$. Epstein places the responsibility for raising children in the home and the responsibility for educating them in the school (Epstein 2001). This strand of the literature on parental involvement focuses on the importance of parents becoming informed about their children's daily school activities, volunteering their services at school functions and for extramural activities and communicating with their children's teachers. Nargis and Tikly (2010) even propose that schools offer an educational path to engage parents who lack knowledge of how the schools in their community function. An interesting aspect of this strand of the literature is that the researchers all propose a compliancy role for parents in the school, giving them supportive roles that could lead to good schooling experiences for their children. Epstein's model (1985) represents a typology of the ways in which parents should be involved in the education of their children. She identifies six fundamental types of involvement: parenting, communicating, volunteering, learning at home, decision-making and collaborating with the community (2001). Beyond the focus on 'how' parents are involved, Epstein (2001) also argues that the families and communities, together with the schools, represent 'overlapping spheres of influence' on the education of children, thereby focusing the attention of educators on the relations within those overlapping spheres. An interesting aspect of models such as Epstein's is that the valued activities for parents are primarily designed to serve the school's priorities of increasing achievement and are seldom aimed at meaningful relationships with parents themselves or in fully engaging them in a broadly defined educational agenda. Such models of parental support focus on the primary interests of the schools, namely to make them function more efficiently (Epstein 2001; Lemmer 2007; Nargis \& Tikly 2010; Singh et al. 2004).

In the literature on parental support, new work is emerging on the experiences of minority and immigrant families in the education of their children (Smrekar \& Cohen-Vogel 2001). According to the study by Taliaferro, DeCuir-Gunby and Kara (2009), immigrants from certain cultures struggle to assimilate into their new culture. For such parents, participation in their children's schooling is not automatic. These immigrant parents struggle to understand the mechanics of the education system in their new country and often do not know where to seek information on how the system works and what is expected of them as parents (Drummond \& Stipek 2004). In countries where parents are expected to be active participants in the educational system, lack of involvement might be misconstrued as apathy or disinterest in their children's education. The research by Li (2010) and Weininger and Lareau (2003) found that social class serves as a mediator of parenting practices, as well as of children's ability to navigate school. Most conceptual models concede that a family's social class, as expressed through the values parents pass on to their children, exerts a powerful influence on the life chances of such children. Even so, they fail to give due recognition to how social class also equips those who have the cultural resources to effectively navigate their environments. Weininger and Lareau (2003) use Bourdieu's cultural capital theory to explain how the cultural experiences of children from middle-class homes differentially aid their adjustment to school and their academic achievements. The parents of such children also know what is expected of 
them. Bourdieu (1977) refers to these resources as accumulated capital that holds important social profits for such family members.

Epstein and Dauber (1991), Lareau (2002), López (1999, 2001) and Waterman (2008) in their research have argued that the types of activities that are valued by schools tend to reflect expectations with which only middle-class parents can engage. These activities require flexibility in parents' working schedules, as well as cultural knowledge about how schools work and what the schools' expectations are. Parents from societies where it is frowned upon for them to share responsibility with teachers for educating children will not automatically know about the school's expectations for them. Conversely, with parents who come from societies where parents take on a much more active role in the school openness is needed on the part of educators to learn new ways to define the relations between parents and schools. My assumption is that schools differentially extract social capital, in unequal amounts, from their diverse parent communities and that they have a partiality for the economic, dominant or intellectual elites. Parents with low socioeconomic standing and marginal parents, such as immigrants, seldom have membership of hegemonic groupings, which limits their involvement in school activities and makes their influence minimal. Such parents are less likely to serve on the school governing body or be the 'first choice' when the school seeks out collaborators from their school community. The likelihood is high that parents will define their role in their children's schooling as informed by and as a function of how the school's educators treat them or engage with them. The rest of this article reports on the research with Somali parents.

\section{Settling on foreign soil: The Somali community in South Africa}

A community is essentially a social world with an 'accumulated history' (Bourdieu 1986:241). The Somali civil war of 1991 led to the displacement of huge numbers of its population. It is estimated that 300000 Somalis migrated to east and southern Africa (Jinnah 2010). While Somali immigrants with refugee status are accommodated in camps in other countries, South Africa has allowed them to integrate into the broader society. This might account for refugees from Somalia choosing to settle in post-apartheid South Africa rather than other African countries. As a signatory of the UN Convention for Refugees (UNHCR 2000), South Africa is obliged to grant any refugee child the opportunity for an education. Somalis have settled around those communities that have an infrastructure that includes mosques and community schools. This is confirmed by Jinnah's research (2010), which attributes the Somalis' preference for the Western Cape to the province's strong Muslim presence.

The town where my research was conducted has an established Somali community. The first nine adults settled there in 1997, which means that some families have been living in the town for almost two decades. Though they seem to prefer to have Muslim families as neighbours, the Somalis have created their own micro-community in this formerly coloured township. They are culturally, ethnically and linguistically very different from Muslim South Africans. What they do share, however, is the local Muslim primary school. The school's registry shows that the first Somali pupil enrolled in 2002. By 2013, there were 12 Grade R pupils and 18 Grade 1 pupils, and in 2014, this community's children made up more than $50 \%$ of the English Grade 1 class. These statistics point to the growing presence in the schools of immigrant children who come from homes where the schools' languages of instruction are foreign to the parents. Not enough is known about how immigrant parents support the academic work of primary school children. Here I share the findings of a study I conducted with Somali parents on their role in the educational success of their children.

\section{Educational background of parents}

Teachers give prominence to parental involvement as a tool to advance educational outcomes for their children. Research backs the merits of parent involvement in schooling and promotes techniques for increasing it (Weininger \& Lareau 2003). According to Bernstein (2004), educational acquisition is strengthened and augmented by allotting time at home to do homework. The educational investments of parents, however, are influenced by the parents' own educational experiences and their competency in assisting their children with homework and educational projects. I found that Somali parents lacked the competencies needed to help their children with homework, which the teachers then interpreted as a lack of interest by the parents and a lack of investment in their children. This situation was made much more complex when the parents had no formal experience of school.

Both in my study and that of Peters (2014), the Somali parents, with the exception of one participant, had had no access to formal basic education as children. As all the participants were women, I analysed their educational experience through a gendered lens. According to them, Somalian girls traditionally did not receive a secular education, although they did attend madrassa and were schooled to read the Quran. Religious education occupied a strategic place in their families and the transference of a religious value system in their formative years was given priority over secular education. Traditionally, these values were taught at the madrassa, as part of their preparation for the adult world and for parenthood. While growing up, the parents were thus engaged in alternative forms of education. Their narratives confirm the existence of a pedagogical context in their childhood homes. Although parents like Afifa ${ }^{1}$ and Malaika never formally went to school, in their homes they had been exposed to their parents reading from the Quran and had had access to objectified forms of cultural capital such as books and newspapers. Malaika's mother, who was one of the privileged few who had gone to school, monitored and encouraged her to engage in school-related activities at home. She taught Malaika to read in Somali, and one of the

1.Pseudonyms were used for all participants. 
prized possessions Malaika brought from Somalia was a bilingual dictionary. Despite their lack of secular schooling, these parents had various forms of cultural capital saved, which became mechanisms that guided their own decisions and actions concerning the education of their children.

\section{Literacy as mediator of educational support in the home}

The medium of instruction in the school that their children attend is English, and the first additional language is Afrikaans. The parents in the community lack competency in both these languages. Even had they attended formal schools in Somalia, the system there would have been vastly different from the Anglophone school system of South Africa. I identified the intersection of their lack of formal schooling with their limited proficiency in English as a factor contributing to how they participated in the educational lives of their children.

Shakira and Afifa, who were both semi-literate, were constantly reminded of their lack of operational skills when their children brought home schoolwork. They experienced feelings of inferiority when they could not assist their young children who were in the lower grades. Thus, even when they wanted to help, they were unable to do so, as they could not read the instructions. However, instead of giving up, these parents started to capacitate themselves with skills that would make it possible for them to execute the sanctioned school-related activities. Their narratives place the English language central to all educational acts, especially their facilitation of educational practices at home. As the data show, these parents seemed to be quite proactive in the ways that they went about acquiring or improving their linguistic competency in English.

Of the women I interviewed, only Amirah knew English before she arrived in South Africa. She was in the first group who settled in the town, and the only one who could speak some English. The others had only heard English being spoken on television. The women said that before their children were of schoolgoing age, they had had only limited opportunities to acquire English. The reason they gave was that Somali women were socialised to keep to themselves and not to mix with the broader town community. It was only when they had school-age children that the need to learn English became a priority for them. At the time of the interviews, all the women were conversant in English. All said that they had acquired English through engagement with television and through practising alongside their primary school children. In my conversations with Malaika and Afifa, I was impressed with their extensive vocabulary. They informed me that they had acquired their conversational competencies through watching soap operas on television. They also practised their English with their children and with outsiders. It was interesting to observe how successful they were in creating dialogical spaces for themselves and their children. Their supervision of their children's homework seemed to have opened up educational opportunities for them to learn alongside their children. Their narratives contained many examples of how they sought ways to circumvent their own educational shortcomings. Two of the mothers could not read or write in English, though they could speak the language. What they did during homework time was to mimic the supervision process. They would praise the child for doing the homework and tell him he was doing well, though they were not themselves able to monitor whether the work was being done correctly. Afifa said she got away with this act because her younger children did not know that she could not read or write in English. It was not unusual for Afifa and Shakira to instruct their younger children to read to them, even though they did not yet have the capability to verify whether their children were reading correctly. According to Afifa, she used her cell phone as a strategic educational tool, encouraging her children to read SMS messages to her so as to strengthen their reading skills. These actions of the parents send out a strong message that education is important. Their narratives challenge the perception that incomplete homework, poorly done projects and incorrect answers are evidence of a lack of interest and investment by the parents.

\section{Drawing dividends from the social capital that they accumulated}

Malaika and Amirah settled in the town more than two decades ago. Afifa and Shakira arrived less than 10 years ago. My analysis of their narratives shows that the families who have been in South Africa longest have over the years built up community cultural capital (Yosso 2005). Their older children are now in high school, and these children have become resources that the parents can use to advance the education of the younger primary school siblings. Malaika and Amirah's families, through an exchange of resources within and among the family members, are able to cope with schooling challenges differently from Afifa and Shakira's families. Their narratives bring into focus the intergenerational benefits that can be enjoyed when parents and siblings become literate. Furthermore, they have established support networks and systems, both within the family and beyond, which when needed can serve as important sources of social capital. When Amirah's firstborn started school, she faced similar constraints to Afifa and Shakira. She did not have the competency to assist her children academically. She approached a retired teacher from the local community to supervise their homework, as neither she nor her husband had the skills or the knowledge to help them. Afifa is now in a similar situation, but has more options to explore.

Two decades later, more networks are available to the Somali parents. Now there are high school children in the community, who, for a small fee, make their services available to families such as Afifa's and Shakira's. These parents are aware of the learning support that the school can provide to struggling students, through a teacher who has been appointed in this specialist position. They also make use of the services of an after-school programme, which offers extra tutoring in languages and mathematics, the particular learning areas in which their children need help. 
The narratives also contain examples that speak to the aspirational capital that the parents accumulate towards their children's futures. It confirms that they are involved parents who are engaging with education as an investment in their children's futures. The data show that, besides the pedagogical, there are other forms of support that parents provide that indirectly enhance their children's pedagogical development in school. Amirah, for example, builds her children's confidence and hones their skills by investing in their educational future. When she buys them a book, they have to present to the family what they have learnt from it. Amirah and her husband have also started buying books on the various careers in which their children show an interest, so that they are informed about such professions. She has a permanent arrangement with her younger children to accompany them on a Friday afternoon to the municipal library. When asked about her commitment to education, she shared the story of how she and her husband constantly use their refugee experience to encourage their children to achieve academically. He tells them: 'We do not want you to struggle, like your mother and I struggled'.

Education offers an opportunity for a better life for their children. The parents all have dreams and aspirations for their children. They consider their children's generation as fortunate in having access to equal opportunities in South Africa. These parents all spent their childhood years in a Kenyan refugee camp, growing up without access to education. Given their childhood experiences, as parents they were thankful to raise their children in South Africa. They see opportunities for them to advance academically. All their children of schoolgoing age were attending school. Malaika and Amirah, who were among the first settlers, had children who had already graduated from high school. Malaika's eldest son is a university student.

\section{Building the parent-teacher relationship}

Every school expects parents to be involved in the activities, programmes or meetings that the school schedules. None of the teachers who took part in the focus group seemed to have established relationships with parents or involved them in a meaningful way in their children's education. In my interviews with the teachers, they appeared to have very limited knowledge about the backgrounds of the immigrant children or of their parents. Though some commented that the Somali mothers were regular visitors to the school, their limited knowledge about these mothers suggested that their engagements with them were on an ad hoc basis. The teachers' attitude to parents' role in education mirrored those found in the research (Epstein 1995, 2001; Nargis \& Tikly 2010). They expected the parents to be amenable to communication about their children's educational work, to be knowledgeable about daily school activities and homework, to volunteer their services at school functions and extramural activities and to support the school. None of them acknowledged the roles that the parents themselves performed at home and which indirectly contributed to the successes that the teachers had with their children in school.
Amirah and Afifa visit the school on a regular basis. Amirah has great respect for her children's teachers, saying that one of them 'teaches them to be proud of who they are'. She saw teachers as surrogate parents and did not make a distinction between the teacher's and the parents' roles in the child's life. For her, their roles were similar: 'To raise your child and to teach the child is the same. In the house, in the school, it is the same'.

My analysis of both the parents' and the teachers' narratives on teacher-parent collaboration led me to believe that because the mechanisms and processes of engagement were not always clearly negotiated between these parties, tension, frustration and even conflict arose when they interacted. Although the teachers described the Somali parents as 'very eager to please', some used this as a euphemism to vent about parents whose unofficial, badly timed visits disrupted the workday of the teacher. According to them, most Somali parents did not make appointments to see them. They would arrive unannounced at their classes and insist that the teachers meet with them. They ignored the rules and regulations, which facilitate the smooth running of the school programme.

The typical Somali parent's response to any note that she received from the school was to go immediately to the school and then directly to the class teacher. They seemed to assume that their quickness to respond conveyed to the teacher that they were involved parents. The teachers, however, said that, even when the notes the school sent out were of a generic nature and did not require the parents to visit to school, they still did. The parents were aware of the tensions that their visits elicited in the teachers and were hurt by the teachers' reactions. The data further showed the lack of empathy the teachers had with those parents who had a limited competence in English.

\section{The same community, a different time in their development}

The first thing I experienced when I started my fieldwork was how different the community was from the one I had come to know up close through Peters's (2014) study in 2012. Peters struggled to gain access to the immigrant community. They came across as edgy and suspicious of outsiders, and she had to overcome numerous challenges resulting from the community's misunderstanding of the reasons for her research. All her negotiations to access the community's parents had to be carried out through a male gatekeeper whom the parents referred to as their leader. She had to appoint a male negotiator to liaise on her behalf, as the leader only met with men. Language posed a major barrier to the quality and validity of the data, as most of the potential participants were not conversant in English. In the event, we decided to appoint an interpreter who was known to the community to assist during the interviews.

In 2016, four years later, I was amazed by how the conditions of engagement and the dispositions of community 
members had shifted. The community was more settled, and parents and children seemed to be used to conversing in English, even when some parents did not speak the language fluently. During the interviews, I realised that two of the parents I was interviewing were also initially participants in Peters's study. However, they withdrew from the study before Peters could interview them. All the participants were confident and comfortable with speaking in English. I interviewed one parent at her home, one at the school and two at a venue close to the school. They walked to the venue unaccompanied, which speaks to the freedom of movement for women from this community. Peters found that the community's women were confined to the private space of home and seldom mixed with non-Somalis. Although mothers continue to be the primary homemakers and caregivers, three of the four parents I interviewed were businesspersons.

\section{Ethical considerations}

Pseudonyms were used for all participants in this article.

\section{Discussion}

In this article, I explore the various ways in which the parents in an immigrant community supported their children educationally. Parental involvement is important for educational success. However, not all parents from this community are skilled in the ways that schools value. They consider their own lack of formal school experience and language to be the barriers to providing optimal educational support to their children. This is similar to the findings of Delgado-Gaitan (1992) in her research on Latino parents. Parents who lacked or had limited formal literacy skills in English showed limited participation in the activities that the schools valued. However, despite these challenges, the parents in this study were involved and proactive in their efforts to assist with school-related activities. They exercised agency by building their own capacity and skilling themselves to better support their children's education. They constantly worked on their own functional literacy skills in English and used their children and the broader diverse world in which they functioned as resources. Daily actions and social activities such as sending an SMS or watching television were treated as educational opportunities that could advance intergenerational literacy.

Amirah, Malaika, Afifa and Shakirah all presented with an embodied form of capital, as reflected in their attitudes, dispositions and championing of education. However, the teachers and the school were not always aware of this, as they had no knowledge of the investments that these parents were making in their children. I found the overriding motive for sending their children to school was to ensure quality of life for their children. Education was valued for the opportunity it created for their children to have a better future than the one they had left behind in the refugee camps in Kenya. Their actions and the role that they played showed that they valued education and considered the schooling of their children a necessity. The findings showed that the parents were proponents of education, which positioned them as potential collaborators of the school. However, the study also points out that when teachers lack knowledge about parents and the home contexts of their students, they are unlikely to consider them as collaborators in education. Insight into the challenges these parents navigate to engage with the kind of school-related activities that literate parents take for granted could help to shift the teachers' view of them as being uninvolved in their children's schooling. Insights into the commitment they show in supervising their children's schoolwork, working with them on assignments and their reading, could balance out the negative view that some educators hold of those Somali parents who impose on their school space and ignore the rules and regulations. Were the schools to gain knowledge about the rich cultural capital that such homes have built under these parents' guidance, they could expand the narrow range of educational support activities by which they judge parental participation.

Although this study suggests that these Somali parents lack cultural knowledge about how the school system operates and the rules that govern access, it also unmasks the uncritical engagement of the school with these parents' contributions. A more critical knowledge and understanding is needed of how their cultural difference from the existing school community can lead to miscommunication and feed mistrust in the Somali parents' motives. The research found a scarcity of equitable channels of communication through which teachers and immigrant parents could carry on a dialogue. This is an aspect that should be addressed by the school management, as it is the cause of miscommunication and tension between the school and the immigrant parents. It would be a fallacy to assume that all parents know how schools work. A recommendation then would be that the school orientate parents who are not from the mainstream culture in the ways that the school works, and this should to be done in a language that they understand. Knowledge about how the school operates will gives the Somali parents the individual power to better navigate the school spaces and would further empower them to engage in constructive dialogue with the teachers about how they support the educational project.

\section{Acknowledgements}

I thank the National Research Foundation for their funding of this project through their Competitive Programme for Rated Researchers grant.

\section{Competing interests}

The author declares that she has no financial or personal relationships which may have inappropriately influenced her in writing this article.

\section{References}

Bauch, P.A. \& Goldring, E.B., 1995, 'Parent involvement and school responsiveness: Facilitating the home-school connection in school of choice', Educational Evaluation \& Policy Analysis 17, 1-21. https://doi.org/10.2307/1164267

Bernstein, B., 2004, 'Social class and pedagogical practice', in S.J. Ball (ed.), The Routledge Falmer Reader in sociology of education, pp. 196-218, Routledge, London. 
Bourdieu, P., 1977, Outline of a theory of practice, Cambridge University Press, Cambridge. Bourdieu, P., 1986, 'The forms of capital', in J. Richardson (ed.), Handbook of theory and research for the sociology of education, pp. 241-258, Greenwood, New York.

Chase, S.E., 2005, 'Narrative inquiry: Multiple lenses, approaches, voices', in N.K. Denzin \& Y.S. Lincoln (eds.), The SAGE handbook of qualitative research, $\mathrm{pp}$ 651-680, Sage, Thousand Oaks, CA.

Christian, K., Morrison, F.J. \& Bryant, F.B., 1998, 'Predicting kindergarten academic skills: Interactions among child care, maternal education, and family literacy environments', Early Childhood Research Quarterly 13(3), 501-521. https://doi. org/10.1016/S0885-2006(99)80054-4

Creswell, J.W., 2003, Research design. Qualitative, quantitative and mixed methods approaches, 2 nd edn., Sage, Thousand Oaks, CA.

Daniels, D., 2003, 'Learning about community leadership: Fusing methodology and pedagogy to advance knowledge development on informal settlement women', Adult Education Quarterly 53(3), 189-207. https://doi.org/10.1177/0741713603053003004

Delgado-Gaitan, C., 1992, 'School matters in the Mexican-American home: Socializing children to education', American Educational Research Journal 29, 495-513. https://doi.org/10.3102/00028312029003495

Department of Education, 2004, National Educational Policy, Notice 1950 of 2004 Pretoria, South Africa.

Drummond, K. \& Stipek, D., 2004, 'Parents' beliefs about their role in young children's academic learning', Elementary School Journal 104(3), 197-213. https://doi. org/10.1086/499749

Epstein, J.L., 1985, 'Parents' reactions to teacher practices of parent involvement', Elementary School Journal 86, 568-587.

Epstein, J.L., 1995, 'School/family/community partnerships: Caring for the children we share', Phi Delta Kappan 76, 701-712.

Epstein, J.L., 2001, School, family, and community partnerships, Westview Press, Boulder, $\mathrm{CO}$.

Epstein, J.L. \& Dauber, S.L., 1991, 'School programs and teacher practices of parent involvement of inner-city elementary and middle schools', Elementary School Journal 91, 291-305. https://doi.org/10.1086/461656

Gill, J., 2008, 'Social inclusion for South Australian schooling? Trying to reconcile the promise and the practice', Journal of Education Policy 23(5), 453-467. https://doi. org/10.1080/02680930802054404

Hampton, F.M., Mumford, D.A. \& Bond, L., 1998, 'Parental involvement in inner city schools: The project FAST extended family approach to success', Urban Education 33(3), 410-427. https://doi.org/10.1177/0042085998033003006

Henderson, A.T. \& Mapp, K.L., 2002, A new wave of evidence: The impact of school, family, and community connections on student achievement, Southwest family, and community connections on studen
Educational Development Laboratory, Austin, TX.

Jeynes, W.H., 2005, 'A meta-analysis of the relation of parental involvement to urban elementary school student academic achievement', Urban Education 40(3) 237-269. https://doi.org/10.1177/0042085905274540

Jeynes, W.H., 2007, 'The relationship between parental involvement and urban secondary school student academic achievement: A meta-analysis', Urban Education 42(1), 82-110. https://doi.org/10.1177/0042085906293818

Jinnah, Z., 2010, 'Making home in a hostile land: Understanding Somali identity, integration, livelihood and risks in Johannesburg', Journal of Sociology and Socia Anthropology 1(1-2), 91-99.

Lareau, A., 1989, Home advantage, Falmer, New York.

Lareau. A., 2002, 'Invisible inequality: Social class and childrearing in black families and white families', American Sociological Review 67(5), 747-776. https://doi. org/10.2307/3088916

Lemmer, E.M., 2007, 'Parent involvement in teacher education in South Africa', International Journal about Parents in Education 1, 218-229.

Li, G., 2010, 'Social class, culture and "good parenting": Voices of low-SES families', in M.M. Marsh \& T. Turner-Vorbeck (eds.), Learning from real families in our school, pp. 162-178, Teachers College Press, New York.
Liamputtong, P. \& Ezzy, D., 2005, Qualitative research methods, 2nd edn., Oxford University Press, South Melbourne.

López, G.R., 1999, 'Teaching the value of hard work: A study of parental involvement in migrant households', unpublished doctoral dissertation, University of Texas, Austin.

López, G.R., 2001, 'The value of hard work: Lessons on parent involvement from an (im)migrant household', Harvard Education Review 71, 416-437. https://doi. org/10.17763/haer.71.3.43x7k542x023767u

McBride, B.A. \& Lin, H., 1996, 'Parental involvement in prekindergarten at-risk programs: Multiple perspectives', Journal of Education for Students Placed at Risk 1(4), 349-372. https://doi.org/10.1207/s15327671espr0104_5

Mertens, D., 2014, Research and evaluation in education and psychology: Integrating diversity with quantitative, qualitative, and mixed methods, Sage, Thousand Oaks, CA.

Nargis, R. \& Tikly, T., 2010, Guidelines for inclusion and diversity in schools, British Council, Madrid, Spain.

Orellana, M.F., Monkman, K. \& MacGillivray, L., 2002, Parents and teachers talk about literacy and success, CIERA report \#3-020, Center for the Improvement of Early Reading Achievement, University of Michigan, Ann Arbor, MI, viewed 20 February 2015, from http://www.ciera.org/library/reports/inquiry-3/3-020/3-020h.html

Patton, M.Q., 2002, Qualitative research and evaluation methods, Sage, Thousand Oaks, CA.

Peters, L., 2014, 'Somali parents' educational support of their primary school children', unpublished MEd thesis, Stellenbosch University, viewed from http://hdl.handle. net/10019.1/86307

Republic of South Africa, 1996a, South African constitution, Government Printers, Pretoria, South Africa.

Republic of South Africa, 1996b, South African Schools Act, Government Printers, Pretoria, South Africa.

Republic of South Africa, Department of Education, 1995, White paper on education and training, viewed 10 February 2014, from www.info.gov.za/whitepapers/1995/ education1.htm

Singh, P., Mbokodi, S.M. \& Msila, V.T., 2004, 'Black parental involvement in education', South African Journal of Education 24(4), 301-307.

Smrekar, C. \& Cohen-Vogel, L., 2001, 'The voices of parents: Rethinking the intersection of family and school', Peabody Journal of Education 76(2), 75-100. https://doi. org/10.1207/S15327930pje7602

Swart, E. \& Pettipher, R., 2011, 'A framework for understanding inclusion', in E. Landsberg, D. Krüger \& E. Swart (eds.), Addressing barriers to learning: A South African perspective, 2nd edn., pp. 3-26, Van Schaik, Pretoria.

Taliaferro, J.D., DeCuir-Gunby, J.T. \& Allen-Eckard, K., 2009, 'I can see parents being reluctant: Perceptions of parental involvement using child and family teams in schools', Child and Family Social Work 14, 278-288. https://doi. org/10.1111/j.1365-2206.2008.00594.x

Terre Blanche, M., Durrheim, K. \& Painter, D., 2006, Research in practice: Applied methods for the social sciences, 2nd edn., UCT Press, Cape Town.

UNESCO, 1960, Convention against discrimination in education, UNESCO, Paris.

UNHCR, 2000, The state of the world's refugee: 50 years of humanitarian action, Oxford University Press, Oxford, United Kingdom.

United Nations, 1948, The Universal declaration on human rights, UN, Paris.

Waterman, R.A., 2008, 'Strength behind the sociolinguistic wall: The dreams, commitments, and capacities of Mexican mothers', Journal of Latinos and Education 7(2), 144-162. https://doi.org/10.1080/15348430701828715

Weininger, E.B. \& Lareau, A., 2003, 'Cultural capital in educational research: A critical assessment', Theory and Society 32, 567-606. https://doi.org/10.1023/ B:RYSO.0000004951.04408.b0

Yosso, T., 2005, 'Whose culture has capital? A critical race theory discussion of community cultural wealth', Race, Ethnicity and Education 8(1), 69-91. https:// doi.org/10.1080/1361332052000341006 